\title{
(6) OPEN ACCESS \\ Postinduction serum infliximab trough level and decrease of C-reactive protein level are associated with durable sustained response to infliximab: a retrospective analysis of the ACCENT I trial
}

\author{
Freddy Cornillie, ${ }^{1}$ Stephen B Hanauer, ${ }^{2}$ Robert H Diamond, ${ }^{3}$ Jianping Wang, ${ }_{1}{ }^{4}$ \\ Kezhen L Tang, ${ }^{4}$ Zhenhua $\mathrm{Xu}_{1}{ }^{5}$ Paul Rutgeerts, ${ }^{6}$ Séverine Vermeire ${ }^{6,7}$
}

\begin{abstract}
'Department of Immunology, Janssen Biologics BV, Leiden, The Netherlands ${ }^{2}$ Departments of Gastroenterology, Hepatology, and Nutrition, The University of Chicago Medicine, Chicago, Illinois, USA

${ }^{3}$ Medical Group, Janssen Biotech, Inc, Horsham Pennsylvania, USA ${ }^{4}$ Biostatistics and Programming, Janssen Research \& Development, LLC, Horsham, Pennsylvania, USA ${ }^{5}$ Biologics Clinical

Pharmacology, Janssen Research \& Development, LLC, Spring House, Pennsylvania, USA

${ }^{6}$ Department of

Gastroenterology, University Hospital Gasthuisberg, $\mathrm{KU}$ Leuven, Belgium ${ }^{7}$ National Fund for Scientific Research (FWO), Flanders, Belgium
\end{abstract}

\section{Correspondence to} Dr Freddy Cornillie, Department of Immunology, Janssen Biologics BV, Archimedesweg 29, 2333 CM Leiden, The Netherlands; fcornill@its.jnj.com

Received 5 November 2012 Revised 6 January 2014 Accepted 7 January 2014 Published Online First 28 January 2014

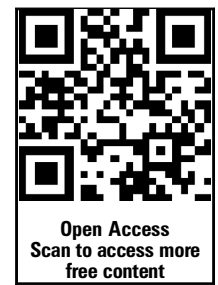

\section{ABSTRACT}

Background Serum infliximab trough levels correlate with efficacy; dose escalation is often beneficial in patients with Crohn's disease who stop responding to infliximab treatment.

Objective To carry out a post hoc analysis of A Crohn's Disease Clinical Trial Evaluating Infliximab in a New Long-term Treatment Regimen I (ACCENT I) to evaluate the association between serum infliximab trough levels and C-reactive protein (CRP) after 14 weeks of induction treatment with durable sustained long-term response (Crohn's Disease Activity Index decrease $\geq 70$ points and reduction $\geq 25 \%$ from baseline).

Design ACCENT I was a multicentre, randomised, placebo-controlled study. Week 14 trough levels and CRP percentage decrease from baseline to week 14 were compared between patients with and without durable sustained response through week 54 . Sensitivity and specificity were determined to predict durable sustained response. Receiver operating characteristic (ROC) curves identified optimal cut-off points; logistic regression determined ORs.

Results After induction with $5 \mathrm{mg} / \mathrm{kg}$ infliximab, 25\% (37/147) and 33\% (47/144) of patients sustained week 14 response to infliximab 5 or $10 \mathrm{mg} / \mathrm{kg}$, respectively, administered every 8 weeks without dose escalation, through week 54. Median week 14 trough levels of patients with and without durable sustained response to infliximab $5 \mathrm{mg} / \mathrm{kg}$ were 4.0 and $1.9 \mu \mathrm{g} / \mathrm{mL}$, respectively $(p=0.0331)$. Optimal predictors of durable sustained response to maintenance infliximab $5 \mathrm{mg} / \mathrm{kg}$ were week 14 trough level $\geq 3.5 \mu \mathrm{g} / \mathrm{mL}$ and $\geq 60 \%$ CRP decrease (ORs ( $95 \% \mathrm{Cl}), 3.5$ (1.1 to 11.4) and 7.3 (1.4 to 36.7$)$ ), respectively, in patients with raised baseline CRP $(>8.0 \mathrm{mg} / \mathrm{L})$; area under the ROC curve was 0.75 for both predictors. $A \geq 3.5 \mu \mathrm{g} / \mathrm{mL}$ week 14 infliximab serum level did not predict durable sustained response to $10 \mathrm{mg} / \mathrm{kg}$ maintenance infliximab.

Conclusions Patients with durable sustained response to maintenance infliximab $5 \mathrm{mg} / \mathrm{kg}$ had higher postinduction trough levels than patients without durable sustained response. Serum infliximab trough levels $\geq 3.5 \mu \mathrm{g} / \mathrm{mL}$ and $\geq 60 \%$ CRP decrease were significantly associated with durable sustained response.

\section{INTRODUCTION}

Anti-tumour necrosis factor (TNF) therapies, such as infliximab, a chimeric monoclonal antibody against TNF, have been effective in inducing and

\section{Significance of this study}

What is already known about this subject?

- Detectable serum infliximab trough levels are indicative of durable sustained response.

- Antibodies to infliximab are associated with a loss or reduction of clinical benefit.

- Normalisation of C-reactive protein (CRP) levels is associated with the likelihood of durable sustained response.

What are the new findings?

- Patients with baseline immunomodulator use and durable sustained response to $5 \mathrm{mg} / \mathrm{kg}$ infliximab maintenance had significantly higher early median serum infliximab trough levels than patients who lost response.

- Optimal cut-off values, for example, $a \geq 3.5 \mu \mathrm{g} /$ $\mathrm{mL}$ postinduction serum infliximab trough level and $a \geq 60 \%$ CRP decrease from baseline to week 14 , significantly predicted durable sustained response to infliximab $5 \mathrm{mg} / \mathrm{kg}$ maintenance in patients with raised baseline CRP.

How might it impact on clinical practice in the foreseeable future?

- Measurement of serum infliximab trough levels and the decrease in CRP soon after induction may be indicative of durable sustained long-term response without dose escalation and potentially guide dose increases to sustain responses in patients with low trough levels or inadequate CRP responses.

maintaining remission in Crohn's disease $(C D)^{1}$; however, the rate response loss after 12 months ranges from $23 \%$ to $46 \%$ in patients with CD treated with infliximab or adalimumab. ${ }^{2}$ This loss of response has been associated with undetectable serum infliximab trough levels related to the development of antibodies to infliximab (ATIs), ${ }^{3}{ }^{4}$ and with rapid drug clearance, where anti-TNF antibodies neutralise the effects of any anti-TNF therapies. ${ }^{2}$ Detectable infliximab trough levels have also been associated with higher rates of clinical remission, while lower C-reactive protein (CRP) levels and higher rates of endoscopic improvement in 
$\mathrm{CD}^{3}$ suggest that serum infliximab trough levels may be an important predictor of CD treatment outcomes. As a valuable marker of CD activity, CRP levels correlate with mucosal inflammation and higher probability of clinical relapse.

In addition, low serum infliximab trough levels are one contributing factor that may explain the loss of primary response followed by the need for dose escalation. Limited data are available on the long-term management and outcome of dose escalation after the loss of primary response to infliximab due to decreasing infliximab trough levels in patients with CD. Although trough levels have been correlated with response, ${ }^{3}$ it is still unknown if higher sustained serum infliximab trough levels from the end of induction treatment predict better long-term outcomes than those resulting from dose escalation after loss of response. Furthermore, if detectable early infliximab trough levels after induction treatment result in better long-term clinical outcomes, then a target threshold or concentration range may potentially be identified.

We hypothesised that patients with CD with durable sustained long-term response to infliximab without dose escalation would have higher serum infliximab trough levels after induction and that those serum levels would stay above a certain therapeutic threshold during response. We examined the subgroup of patients with and without durable sustained response to the scheduled maintenance infliximab 5 and $10 \mathrm{mg} / \mathrm{kg}$ treatment in A Crohn's Disease Clinical Trial Evaluating Infliximab in a New Long-term Treatment Regimen I (ACCENT I), a phase 3, multicentre, randomised, placebo-controlled study. This report is a post hoc analysis of ACCENT I data, aimed at better understanding the role of early postinduction serum infliximab trough levels in predicting durable sustained response in CD.

\section{PATIENTS AND METHODS \\ Patients}

The details of ACCENT I (February 1999 to March 2001) have been reported previously. ${ }^{1}$ Patients with moderate-to-severe CD who received 5-aminosalicylates, corticosteroids or azathioprine/ 6-mercaptopurine were treated with scheduled maintenance infliximab 5 or $10 \mathrm{mg} / \mathrm{kg}$ treatment in ACCENT I and were included in this analysis. ${ }^{1}$ Durable sustained response was defined by a decrease of $\geq 70$ points and $\geq 25 \%$ reduction from baseline in the Crohn's Disease Activity Index (CDAI) score at every postinduction study visit (ie, at weeks 14, 22, 30, 38, 46 and 54) without any need for dose escalation (sustained response). The first postinduction serum infliximab trough level that could be assessed was at week 14 .

\section{Outcome of infliximab induction treatment}

In ACCENT I, 58\% (335/573) of patients responded at week 2 to the initial (week 0) infusion of infliximab $5 \mathrm{mg} / \mathrm{kg}$. After full induction with $5 \mathrm{mg} / \mathrm{kg}$ infusions, 192 patients were assigned to scheduled maintenance infliximab $5 \mathrm{mg} / \mathrm{kg}$ treatment at week 14 . Nearly half the patients $(44 \%(85 / 192))$ completed the 52 -week maintenance treatment with scheduled infliximab $5 \mathrm{mg} / \mathrm{kg}$ infusions, while $30 \%(58 / 192)$ of patients lost response and crossed over to episodic treatment with infliximab $10 \mathrm{mg} / \mathrm{kg}$, and another 26\% (49/192) of patients discontinued treatment for various reasons. In this maintenance infliximab $5 \mathrm{mg} / \mathrm{kg}$ group, $75 \%(144 / 192)$ of patients had baseline and week 14 CRP values and week 14 serum infliximab levels. The numbers of patients who continued maintenance $5 \mathrm{mg} / \mathrm{kg}$ treatment with consecutive visits and with assessment of clinical response were 147 (at week 14), 120 (week 22), 106 (week 30), 96 (week 38), 83 (week 46) and 76 (week 54). One hundred ninety-three patients received full induction with three doses of infliximab $5 \mathrm{mg} / \mathrm{kg}$ and were then assigned to scheduled maintenance infliximab $10 \mathrm{mg} / \mathrm{kg}$ at week 14 with $10 \mathrm{mg} / \mathrm{kg}$ infusions given every 8 weeks. Twenty-six per cent $(51 / 193)$ of patients lost response and crossed over to episodic infliximab $15 \mathrm{mg} / \mathrm{kg}$, while another $19 \%$ (37/193) discontinued treatment for various reasons. ${ }^{5}$ In this maintenance $10 \mathrm{mg} / \mathrm{kg}$ group, 73\% (140/193) of patients had baseline and week 14 CRP values and week 14 serum infliximab levels. The numbers of patients who continued maintenance $10 \mathrm{mg} / \mathrm{kg}$ treatment with consecutive visits and with assessments of clinical response were 144 (week 14), 106 (week 22), 97 (week 30), 89 (week 38), 84 (week 46) and 76 (week 54).

\section{Study design}

This post hoc analysis assessed the usefulness of early (week 14) serum infliximab trough levels in predicting sustained response without dose escalation in patients randomised to scheduled maintenance infliximab 5 or $10 \mathrm{mg} / \mathrm{kg} .{ }^{15}$ Patients included in this analysis were responders at week 14; all received a full induction schedule of infliximab $5 \mathrm{mg} / \mathrm{kg}$ infusions given at weeks 0,2 and 6. At week 14 in ACCENT I, patients were randomised to receive every- 8 -weeks maintenance infliximab treatment with a 5 or $10 \mathrm{mg} / \mathrm{kg}$ dose. Both the 5 and $10 \mathrm{mg} / \mathrm{kg}$ maintenance arms thus received the same induction treatment with $5 \mathrm{mg} / \mathrm{kg}$ doses given at weeks 0,2 and 6 . Week 14 infliximab trough levels and percentage decrease of CRP from baseline to week 14 (CRP decrease) in patients with raised baseline CRP levels $(>8.0 \mathrm{mg} / \mathrm{L})$ were assessed as potentially meaningful parameters for predicting sustained response. In ACCENT I, serum infliximab levels were measured at weeks $0,2,6,14,22$, 30, 38, 46 and 54; ATIs were assessed at weeks 0, 14, 22 and 54. Serum infliximab levels were measured with a sandwich enzyme immunoassay (Charles River Laboratories, Inc (formerly Tektagen, Inc), Wilmington, Massachusetts, USA); ATIs were measured with a double-antigen ELISA (Janssen Biotech, Inc (formerly Centocor, Inc), Malvern, Pennsylvania, USA), as previously described. ${ }^{6}$

Because ATIs cannot be reliably measured with ELISA in the presence of serum infliximab, samples with measurable serum infliximab were deemed inconclusive for ATIs. Inconclusive ATI samples had a serum infliximab concentration of $>0.1 \mu \mathrm{g} / \mathrm{mL}$ (ELISA detection limit). Samples that were ATI-positive or ATI-negative had no measurable infliximab $(<0.1 \mu \mathrm{g} / \mathrm{mL})$. Serum CRP levels were analysed with a high-sensitivity, particle-enhanced turbidimetric assay (Roche Diagnostics, Indianapolis, Indiana, USA; detection limit, $0.03 \mathrm{mg} / \mathrm{L}$; normal CRP upper limit, $8.0 \mathrm{mg} / \mathrm{L})$.

Study procedures were performed in accordance with the institutional review board at each study site and with the principles of the Declaration of Helsinki. All patients provided written informed consent in ACCENT I (ClinicalTrials.gov, NCT00207662).

\section{Statistical analysis}

All analyses were performed using SAS v.9.1 and v.9.2 (SAS Institute Inc, Cary, North Carolina, USA). Receiver operating characteristic (ROC) curves were constructed for the sensitivity and specificity analyses of week 14 serum infliximab levels and CRP decrease. Optimal cut-off values for the CRP decrease and absolute week 14 serum infliximab trough level $(\mu \mathrm{g} / \mathrm{mL})$, used to discriminate between patients with and without sustained response, were determined by ROC curves; sensitivity, specificity, and positive and negative predictive values (PPV, NPV, respectively) of the cut-off values and their combined 
associations were analysed. Using the $\chi^{2}$ test, the proportions of patients achieving sustained response were compared between the patients who reached the optimal cut-off point of the week 14 serum infliximab trough level and those who did not. Median (IQR) serum infliximab trough levels were compared between patients with and without sustained response using the Mann-Whitney $U$ test. A logistic regression model with forward-step selection, including three dichotomous parameters (week 14 serum infliximab trough level, CRP decrease above or below the selected cut-off point and baseline immunomodulator use) and three continuous variables (week 14 CRP level, week 14 serum infliximab trough level and CRP decrease), was used to select the best-fit parameters predicting sustained response to infliximab $5 \mathrm{mg} / \mathrm{kg}$ through 54 weeks. Change of CDAI score from baseline to week 14 was not entered into this model because the definition of sustained response was defined by the CDAI score change.

\section{RESULTS}

\section{Patients}

Baseline demographic characteristics are described in table 1. Of the 192 and 193 patients in the scheduled maintenance infliximab 5 and $10 \mathrm{mg} / \mathrm{kg}$ treatment groups, only 144 and 140 patients, respectively, had baseline and week 14 CRP and week 14 serum infliximab trough level measurements. Baseline CRP was elevated (CRP $>8.0 \mathrm{mg} / \mathrm{L}$ ) in $49 \%(71 / 144)$ and in $56 \%$ $(80 / 142)$ of patients evaluable for baseline CRP measurements in the 5 and $10 \mathrm{mg} / \mathrm{kg}$ maintenance groups, respectively (table 1). Primary analysis of the predictive value of week 14 infliximab trough level and CRP change from baseline at week 14 in the $5 \mathrm{mg} / \mathrm{kg}$ treatment group was based on patients with raised baseline CRP $(n=71)$.

\section{Outcome of scheduled maintenance infliximab treatment}

Twenty-five per cent (37/147) and 33\% (47/144) of patients had sustained response to scheduled maintenance infliximab 5 or $10 \mathrm{mg} / \mathrm{kg}$ infusions, respectively, at weeks 14, 22, 30, 38, 46 and 54 without any need for dose escalation. At week 14, the median (IQR) serum infliximab trough levels in patients with and without sustained response were 4.0 (1.7 to 6.8) vs $1.9(0.4$ to 4.1$) \mu \mathrm{g} / \mathrm{mL}$ for the $5 \mathrm{mg} / \mathrm{kg}$ group $(\mathrm{p}=0.0331)$ and $4.1(1.7$ to 7.1$)$ vs 1.9 (0.6 to 4.7$) \mu \mathrm{g} / \mathrm{mL}$ for the $10 \mathrm{mg} / \mathrm{kg}$ group $(p=0.1109)$, respectively.
The effect of baseline immunomodulator use on sustaining clinical response without any dose increase through week 54 in the 5 and $10 \mathrm{mg} / \mathrm{kg}$ groups is shown in table 2. Week 14 serum infliximab trough levels were different in patients with and without sustained response when treated with scheduled maintenance infliximab $5 \mathrm{mg} / \mathrm{kg}$ treatment and an immunomodulator (4.6 vs $1.7 \mu \mathrm{g} / \mathrm{mL} ; \mathrm{p}=0.0047$ ) but were not different in patients treated without immunomodulator treatment $(2.6 \mathrm{vs} 2.0 \mu \mathrm{g} / \mathrm{mL}$; $\mathrm{p}=0.3134)$. No serum infliximab trough level differences were seen in any of the patients in the scheduled maintenance infliximab $10 \mathrm{mg} / \mathrm{kg}$ group (table 2 ).

The median (IQR) CRP decrease was $-2.0(-13.0$ to 0.0$)$ $\mathrm{mg} / \mathrm{L}$ in the maintenance infliximab $5 \mathrm{mg} / \mathrm{kg}$ group $(\mathrm{n}=144)$ and $-13.0(-30.0$ to -6.0$) \mathrm{mg} / \mathrm{L}$ in patients with raised baseline CRP $(\mathrm{n}=71)$. The median (IQR) CRP decrease was $-3.0(-17.0$ to 0.0$) \mathrm{mg} / \mathrm{L}$ in the maintenance infliximab $10 \mathrm{mg} / \mathrm{kg}$ group $(\mathrm{n}=140)$ and $-12.0(-25.0$ to -5.0$) \mathrm{mg} / \mathrm{L}$ in patients with raised baseline CRP $(n=80)$. ROC curves were constructed to assign optimal cut-off values associated with sustained response to scheduled maintenance infliximab $5 \mathrm{mg} / \mathrm{kg}$ (figure 1). Areas under the ROC curves were 0.75 for CRP decrease (in patients with raised baseline CRP) and 0.75 for week 14 serum infliximab trough levels. Sensitivity, specificity, PPV and NPV were determined for predicting sustained response to scheduled maintenance infliximab $5 \mathrm{mg} / \mathrm{kg}$ with these two parameters (table 3 ). The $3.5 \mu \mathrm{g} / \mathrm{mL}$ week 14 serum infliximab trough level and $60 \%$ CRP decrease had NPVs of 0.83 and 0.93 , respectively. Sensitivity and NPV further increased to 0.95 and 0.96 , respectively, if the cut-off points, for example, a $3.5 \mu \mathrm{g} / \mathrm{mL}$ week 14 serum infliximab level or a $60 \%$ CRP decrease, were considered in combination (table 3 ).

At week 14, 96/147 patients had serum infliximab trough levels $<3.5 \mu \mathrm{g} / \mathrm{mL}$ and $18 \%$ (17/96) had sustained response to $5 \mathrm{mg} / \mathrm{kg}$ infliximab maintenance through 54 weeks. Fifty-one of 147 patients had week 14 serum infliximab levels $\geq 3.5 \mu \mathrm{g} / \mathrm{mL}$, and $39 \%(20 / 51)$ had sustained response to $5 \mathrm{mg} / \mathrm{kg}$ infliximab maintenance through 54 weeks $(\mathrm{p}=0.0042)$. Overall, about $90 \%$ of patients with week 14 serum infliximab trough levels in quartiles 3 and $4(>2.2$ to $\leq 5.5 \mu \mathrm{g} / \mathrm{mL}$ and $>5.5 \mu \mathrm{g} / \mathrm{mL}$, respectively) and baseline raised CRP $(n=71)$ demonstrated CRP normalisation (figure 2). Conversely, 87\% (20/23) and $38 \%(5 / 13)$ of patients in the lower week 14 serum infliximab level quartiles 1 and $2(\leq 0.6 \mu \mathrm{g} / \mathrm{mL}$ and $>0.6$ to $\leq 2.2 \mu \mathrm{g} / \mathrm{mL}$,

Table 1 Patient baseline characteristics

\begin{tabular}{|c|c|c|}
\hline $\begin{array}{l}\text { ACCENT I scheduled } \\
\text { maintenance group }\end{array}$ & Infliximab 5 mg/kg & Infliximab $10 \mathrm{mg} / \mathrm{kg}$ \\
\hline Randomised patients included in analysis, $\mathrm{n}(\%)$ & $147 / 192(77)$ & $144 / 193(75)$ \\
\hline Age, years, mean (range) & $36.8(18-71)$ & $36.7(19-76)$ \\
\hline Sex, male, $n(\%)$ & $62(42)$ & $59(41)$ \\
\hline \multicolumn{3}{|l|}{ Baseline CDAI } \\
\hline $\mathrm{n}(\%)$ & $146(99)$ & $143(99)$ \\
\hline Median (range) & $300(200-450)$ & $298(200-488)$ \\
\hline \multicolumn{3}{|l|}{ Baseline CRP, mg/L } \\
\hline $\mathrm{n}(\%)$ & $144(98)$ & $142(99)$ \\
\hline Median (range) & $8.0(4.0-117.0)$ & $12.0(4.0-162.0)$ \\
\hline Patients with baseline raised CRP (>8.0 mg/L), $\mathrm{n}(\%)$ & $71(49)$ & $80(56)$ \\
\hline Immunomodulator use, n (\%) & $44(30)$ & $37(26)$ \\
\hline Corticosteroid use, n (\%) & $75(51)$ & $80(56)$ \\
\hline Immunomodulator and corticosteroid use, $\mathrm{n}(\%)$ & $22(15)$ & $17(12)$ \\
\hline
\end{tabular}

ACCENT I, A Crohn's Disease Clinical Trial Evaluating Infliximab in a New Long-term Treatment Regimen I; CDAI, Crohn's Disease Activity Index; CRP, C-reactive protein. 
Table 2 Week 14 serum infliximab trough levels in patients with and without sustained response to scheduled maintenance infliximab 5 and $10 \mathrm{mg} / \mathrm{kg}$ and with and without immunomodulator use

\begin{tabular}{|c|c|c|c|c|}
\hline Treatment & Patients with sustained response & Patients without sustained response & p Value* & All patients \\
\hline Infliximab $5 \mathrm{mg} / \mathrm{kg}$, all patients, $\mathrm{n}$ & 37 & 110 & & 147 \\
\hline Median (IQR), $\mu \mathrm{g} / \mathrm{mL}$ & $4.0(1.7-6.8)$ & $1.9(0.4-4.1)$ & 0.0331 & $2.2(0.6-5.5)$ \\
\hline Patients with immunomodulator use, $\mathrm{n}$ & 15 & 29 & & 44 \\
\hline Median (IQR), $\mu \mathrm{g} / \mathrm{mL}$ & $4.6(2.7-10.6)$ & $1.7(0.6-7.1)$ & 0.0047 & $2.7(1.2-7.2)$ \\
\hline Patients without immunomodulator use, $\mathrm{n}$ & 22 & 81 & & 103 \\
\hline Median (IQR), $\mu \mathrm{g} / \mathrm{mL}$ & $2.6(0.7-6.8)$ & $2.0(0.4-3.8)$ & 0.3134 & $2.2(0.4-5.4)$ \\
\hline Infliximab $10 \mathrm{mg} / \mathrm{kg}$, all patients, $\mathrm{n}$ & 47 & 97 & & 144 \\
\hline Median (IQR), $\mu \mathrm{g} / \mathrm{mL}$ & $4.1(1.7-7.1)$ & $1.9(0.6-4.7)$ & 0.1109 & $2.4(0.9-6.0)$ \\
\hline Patients with immunomodulator use, $\mathrm{n}$ & 14 & 23 & & 37 \\
\hline Median (IQR), $\mu \mathrm{g} / \mathrm{mL}$ & $3.9(0.9-5.8)$ & $2.7(0.6-8.5)$ & 0.4263 & $3.1(0.9-6.8)$ \\
\hline Patients without immunomodulator use, $\mathrm{n}$ & 33 & 74 & & 107 \\
\hline Median (IQR), $\mu \mathrm{g} / \mathrm{mL}$ & $4.5(1.8-7.2)$ & $1.8(0.6-4.2)$ & 0.1278 & $2.2(1.0-5.7)$ \\
\hline
\end{tabular}

${ }^{*} \mathrm{p}$ Value comparing patients with and without sustained response.

respectively) did not have a normalised CRP level. Pearson correlation coefficient of week 14 serum infliximab level and CRP change from baseline at week 14 was -0.020 for the $5 \mathrm{mg} / \mathrm{kg}$ group and 0.025 for the $10 \mathrm{mg} / \mathrm{kg}$ group.

Logistic regression analysis with forward-step selection, including the continuous variables of week 14 serum infliximab trough level, week 14 CRP level and CRP decrease, and the dichotomous variables of $\geq 3.5 \mu \mathrm{g} / \mathrm{mL}$ week 14 serum infliximab trough level, $\geq 60 \%$ CRP decrease and baseline immunomodulator use, showed that a $\geq 3.5 \mu \mathrm{g} / \mathrm{mL}$ week 14 serum infliximab trough level and $\geq 60 \%$ CRP decrease were the best predictors of sustained response to scheduled maintenance infliximab

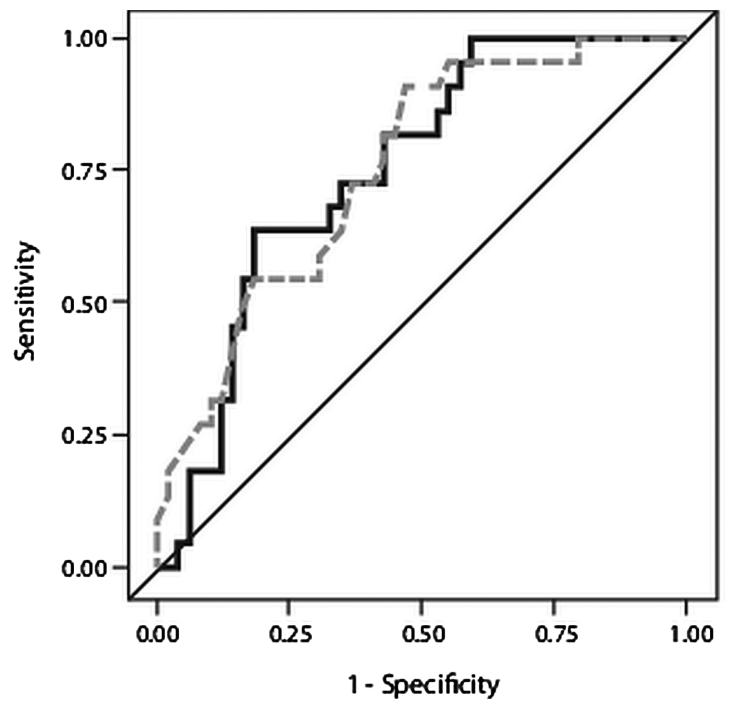

$$
\begin{array}{|c|}
\hline \multicolumn{1}{c|}{\text { Areas under the ROC Curve }} \\
=-=96 \text { CRP decrease in patients with raised CRP }(0.7532) \\
- \text { Serum infliximab trough level in patients with } \\
\text { raised CRP }(0.7505)
\end{array}
$$

Figure 1 Areas under the ROC curve of week 14 serum infliximab trough levels and percentage change of CRP from baseline to week 14 in the scheduled maintenance infliximab $5 \mathrm{mg} / \mathrm{kg}$ group of A Crohn's Disease Clinical Trial Evaluating Infliximab in a New Long-term Treatment Regimen I (ACCENT I) among 71 patients with raised baseline CRP (>8 $\mu \mathrm{g} / \mathrm{mL}$ ). \% CRP decrease: week 14 - baseline (week 0) CRP $\times 100$. CRP, C reactive protein; ROC, receiver operating characteristic.
$5 \mathrm{mg} / \mathrm{kg}$ in this ACCENT I population with ORs (95\% CI) of 3.5 (1.1 to 11.4 ) and 7.3 (1.4 to 36.7$)$, respectively. No other parameters assessed were significant predictors of sustained response to maintenance infliximab $5 \mathrm{mg} / \mathrm{kg}$ in the model.

Serum infliximab trough levels in the 5 and $10 \mathrm{mg} / \mathrm{kg}$ groups were largely overlapping between patients with and without sustained response to these maintenance doses. In the $5 \mathrm{mg} / \mathrm{kg}$ maintenance group, the difference was significant at weeks 6,14 and 22 , whereas in the $10 \mathrm{mg} / \mathrm{kg}$ maintenance dose, the difference was significant at weeks 22 and 38 (figure 3 ). The proportion of patients with sustained response to 5 and $10 \mathrm{mg} / \mathrm{kg}$ infliximab maintenance treatment in relation to immunomodulator use and per quartile of week 14 infliximab trough level is shown in figure 4A-D. Combination treatment with immunomodulator versus monotherapy with infliximab resulted in numerically higher but not significantly different week 14 infliximab trough levels in patients with sustained response to $5 \mathrm{mg} / \mathrm{kg}$ infliximab maintenance treatment ( 4.6 vs $2.6 \mu \mathrm{g} / \mathrm{mL}$; $\mathrm{p}=0.6424)$. As shown in figure $4 \mathrm{~A}, \mathrm{~B}$, sustained response to $5 \mathrm{mg} / \mathrm{kg}$ maintenance treatment is associated with week 14 serum infliximab level in patients with-but not those without-immunomodulator use. In the $10 \mathrm{mg} / \mathrm{kg}$ maintenance group, however, this association was not found (figure 4C,D). Immunomodulator use was not a significant predictor of sustained response to infliximab $5 \mathrm{mg} / \mathrm{kg}$.

Table 3 Accuracy of week 14 infliximab trough levels $\geq 3.5 \mu \mathrm{g} / \mathrm{mL}$ and CRP decrease $\geq 60 \%$ from baseline at week 14 in predicting sustained response in patients with raised baseline CRP $>8 \mu \mathrm{g} / \mathrm{mL}$ given infliximab $5 \mathrm{mg} / \mathrm{kg}$ every 8 weeks without dose escalation $(n=71)$

\begin{tabular}{|c|c|c|c|c|}
\hline & IFX level & $\begin{array}{l}\text { CRP change } \\
\text { from } \\
\text { baseline }\end{array}$ & $\begin{array}{l}\text { IFX level and } \\
\text { CRP change } \\
\text { from baseline }\end{array}$ & $\begin{array}{l}\text { IFX level or } \\
\text { CRP change } \\
\text { from baseline }\end{array}$ \\
\hline $\begin{array}{l}\text { Optimal } \\
\text { cut-off point }\end{array}$ & $3.5 \mu \mathrm{g} / \mathrm{mL}$ & $60 \%$ & $\begin{array}{l}3.5 \mu \mathrm{g} / \mathrm{mL} \text { and } \\
60 \%\end{array}$ & $\begin{array}{l}3.5 \mu \mathrm{g} / \mathrm{mL} \text { or } \\
60 \%\end{array}$ \\
\hline Sensitivity & 0.64 & 0.91 & 0.59 & 0.95 \\
\hline Specificity & 0.78 & 0.53 & 0.82 & 0.49 \\
\hline PPV & 0.56 & 0.47 & 0.59 & 0.46 \\
\hline NPV & 0.83 & 0.93 & 0.82 & 0.96 \\
\hline
\end{tabular}




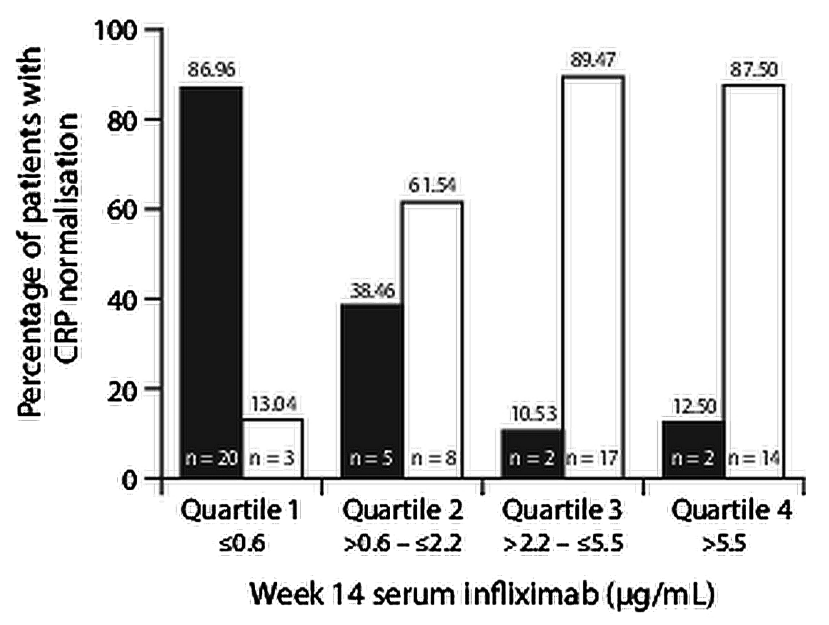

CRP not normalized $\square$ CRP normalized

Figure 2 Association between percentage of patients with CRP normalisation and week 14 serum infliximab trough levels. CRP, $C$ reactive protein.

Detection of ATIs was confounded by the per-ACCENT I-protocol dose increases given after week 14 in patients who lost response; therefore, we report on ATIs at week 14 only. With the insensitive ELISA method used, ATIs could be assessed in only 22/ 147 patients in the $5 \mathrm{mg} / \mathrm{kg}$ arm when infliximab was undetectable in the serum sample. Among these 22 patients, ATIs were negative in 18, positive in two and not assessable in one of the patients without sustained response; one ATI status, which was negative, was assessable among patients with sustained response.

\section{DISCUSSION}

This post hoc analysis of ACCENT I showed that patients with sustained response to scheduled maintenance infliximab $5 \mathrm{mg} / \mathrm{kg}$, but not infliximab $10 \mathrm{mg} / \mathrm{kg}$, and without dose escalation, had higher median week 14 serum infliximab trough levels than those who lost response during the 54-week follow-up: 4.0 vs $1.9 \mu \mathrm{g} / \mathrm{mL}$ $(\mathrm{p}=0.0331)$ and $4.1 \mathrm{vs} 1.9 \mu \mathrm{g} / \mathrm{mL}(\mathrm{p}=0.1109)$ for the maintenance infliximab 5 and $10 \mathrm{mg} / \mathrm{kg}$ groups, respectively. Only patients with sustained response to maintenance infliximab $5 \mathrm{mg} / \mathrm{kg}$ with baseline immunomodulator use had higher week 14 serum infliximab levels than patients without sustained response: 4.6 vs $1.7 \mu \mathrm{g} / \mathrm{mL} \quad(p=0.0047)$. This finding is in agreement with data from the Study of Biologic and Immunomodulator Naïve Patients in Crohn's Disease (SONIC), which showed that clinical outcomes such as corticosteroid-free remission in patients treated with infliximab and azathioprine in combination were associated with higher serum infliximab levels in the combination treatment group. ${ }^{12}$ It is noteworthy that the median week 30 serum infliximab trough level was $3.5 \mu \mathrm{g} / \mathrm{mL}$ in patients treated with combination treatment compared with $1.6 \mu \mathrm{g} / \mathrm{mL}$ in patients treated with infliximab monotherapy in SONIC. ${ }^{12}$

This post hoc analysis also showed that week 14 serum infliximab trough levels and a CRP decrease are significant predictors of sustained response to maintenance infliximab $5 \mathrm{mg} / \mathrm{kg}$ without dose escalation, having ORs of 3.5 and 7.3, respectively. The optimal cut-off points were identified as a $\geq 3.5 \mu \mathrm{g} / \mathrm{mL}$ week 14 infliximab trough level and $\geq 60 \%$ CRP decrease for predicting sustained response to scheduled maintenance inflixi$\mathrm{mab} 5 \mathrm{mg} / \mathrm{kg}$ through 54 weeks. As shown in figure 3 , the serum infliximab trough levels overlap considerably between patients with and without sustained response at all time points. Median infliximab trough levels are different, however, at weeks 6,14 and 22 in the $5 \mathrm{mg} / \mathrm{kg}$ maintenance group and at weeks 22 and 38 in the $10 \mathrm{mg} / \mathrm{kg}$ maintenance group.

Patients who lost response after week 14 had their dose increased (from 5 to $10 \mathrm{mg} / \mathrm{kg}$ or from 10 to $15 \mathrm{mg} / \mathrm{kg}$ ) and were treated episodically from that point onward in both maintenance arms. In this analysis, all patients who lost response at any time after week 14 were recorded in the group of patients without sustained response, and they were eligible for a dose increase. Infliximab pharmacokinetics are linear, and a higher dose results
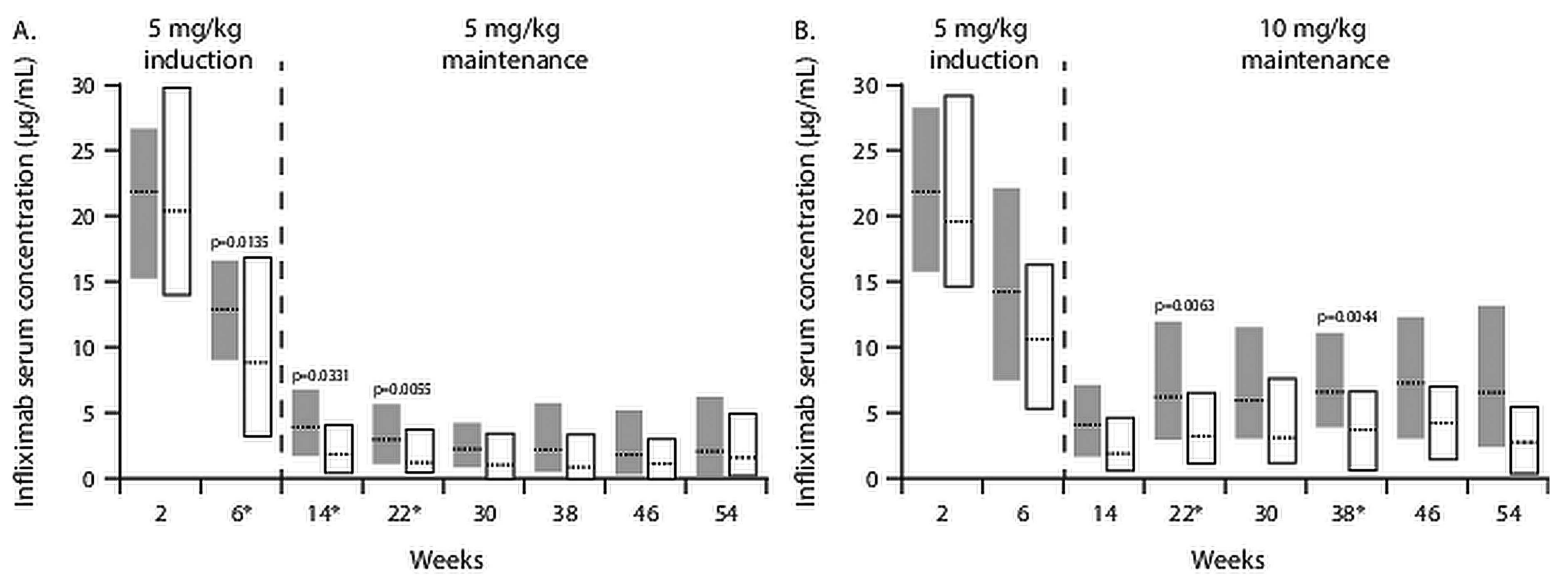

$\begin{aligned} & \text { Patients achieving } \\ & \text { sustained response }\end{aligned} \quad$ Patients not achieving mum Median
sustained response

- Significant difference bet ween patients achieving and not achieving sustained response.

Figure 3 Median (IQR) serum infliximab trough levels in patients with and without sustained response to scheduled maintenance infliximab 5 and $10 \mathrm{mg} / \mathrm{kg}$ through 54 weeks. (A) Median values (IQR) in the $5 \mathrm{mg} / \mathrm{kg}$ maintenance arm are $12.9(9.0-16.6), 4.0$ (1.7-6.8) and 3.0 (1.1-5.6) in patients with sustained response and $8.8(3.2-16.8), 1.9(0.4-4.0)$ and $1.2(0.5-3.8)$ in patients without sustained response at weeks 6,14 and 22 , respectively. (B) In the $10 \mathrm{mg} / \mathrm{kg}$ maintenance arm, these values are $6.2(3.0-12.0)$ and $6.6(3.9-11.1)$ in patients with sustained response and 3.3 $(1.1-6.6)$ and $3.7(0.6-6.7)$ in patients without sustained response at weeks 22 and 38 , respectively. 


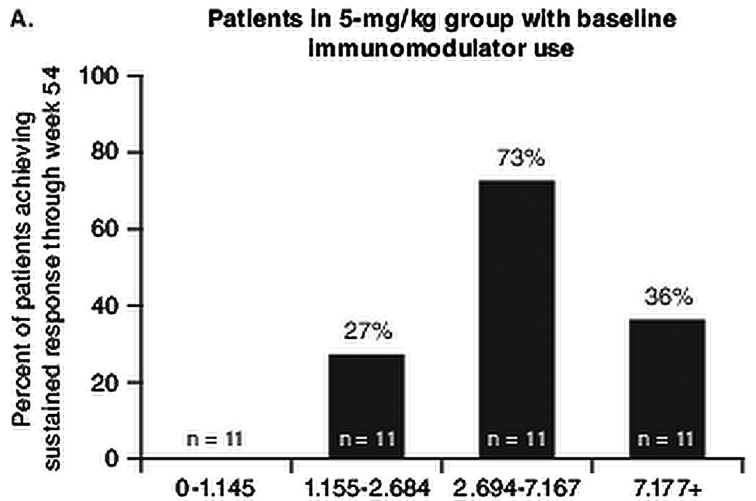

Serum infliximab concentration at week $14(\mu \mathrm{g} / \mathrm{mL})$
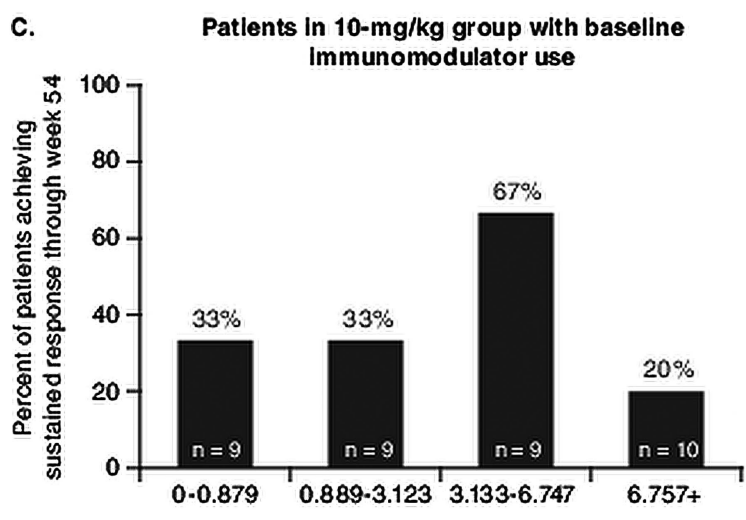

Serum infliximab concentration at week $14(\mu \mathrm{g} / \mathrm{mL})$

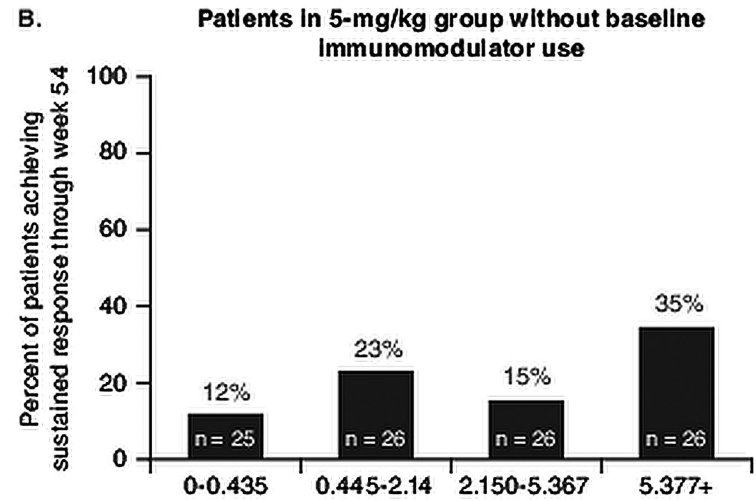

Serum infliximab concentration at week $14(\mu \mathrm{g} / \mathrm{mL})$
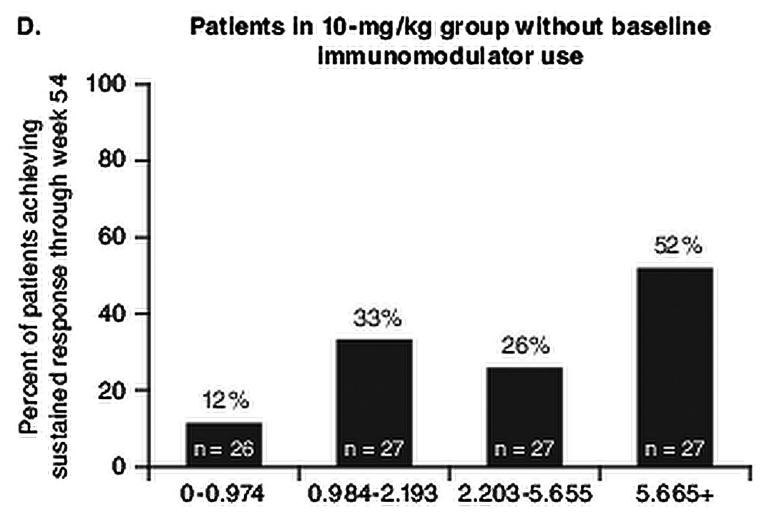

Serum infliximab concentration at week $14(\mu \mathrm{g} / \mathrm{mL})$

Figure 4 Sustained response to $5 \mathrm{mg} / \mathrm{kg}(A$ and $B$ ) and $10 \mathrm{mg} / \mathrm{kg}(C$ and D) infliximab maintenance treatment in relation to immunomodulator use and per quartile of week 14 serum infliximab level.

in higher serum infliximab levels (as shown in figure 3 comparing panels A and B). Serum infliximab trough levels at weeks 2, 6 and 14 , however, are comparable between the 5 and $10 \mathrm{mg} / \mathrm{kg}$ maintenance groups because both groups received the same induction schedule with $5 \mathrm{mg} / \mathrm{kg}$ infusions given at weeks 0,2 and 6 .

The value of CRP for monitoring CD treatment with infliximab is well established. Raised baseline CRP and early CRP normalisation (by weeks 4 or 10) have shown significant correlation with sustained clinical benefit in another ACCENT I post hoc analysis ${ }^{7}$ and in a large single-centre cohort of patients. ${ }^{8}$ While Reinisch et $a l^{7}$ in a previous ACCENT I subanalysis, did not identify an optimum cut-off CRP level at baseline or week 14 in order to predict sustained response to infliximab, patients with raised baseline CRP (>5.0 mg/L) demonstrated CRP normalisation as a significant predictor of sustained response. This post hoc analysis confirmed that while week 14 CRP levels were not a significant predictor of sustained response to maintenance inflixi$\mathrm{mab} 5 \mathrm{mg} / \mathrm{kg}, \mathrm{a} \geq 60 \%$ CRP decrease was a significant predictor. Interestingly, the ROC area under the curve analysis results, using the percentage CRP change from baseline to week 14 and week 14 serum infliximab levels, were the same (0.75). The inverse relationship between week 14 serum infliximab (quartile) levels and proportion of ACCENT I patients with normalisation of (baseline-raised) CRP at week 14 is an important finding (figure 2). Considerably small Pearson correlation coefficients for both the 5 and $10 \mathrm{mg} / \mathrm{kg}$ arms ( -0.020 and 0.025 , respectively) indicate the independence of week 14 serum infliximab level and CRP change at week 14 in this analysis. Combining a $\geq 60 \%$ CRP decrease or a $\geq 3.5 \mu \mathrm{g} / \mathrm{mL}$ week 14 serum infliximab trough level as predictors increased the sensitivity and NPV of the prediction model. This analysis thus confirmed that a $50 \%$ or $60 \%$ decrease and normalisation of CRP are useful predictors of treatment benefit in $\mathrm{CD}$ treatment with infliximab. ${ }^{10}$ Infliximab trough levels may be a useful marker of long-term benefit in the 20-25\% of patients with CD who do not have increased CRP levels in response to active inflammation. ${ }^{8}$

Interestingly, baseline immunomodulator use was not a significant predictor of sustained response to scheduled maintenance infliximab $5 \mathrm{mg} / \mathrm{kg}$ in the stepwise regression analysis. Week 14 serum infliximab levels were numerically higher but not significantly different in patients with sustained response to maintenance infliximab $5 \mathrm{mg} / \mathrm{kg}$ and immunomodulator use (15/37) than in patients with sustained response without immunomodulator use (22/37): 4.6 and $2.6 \mu \mathrm{g} / \mathrm{mL}$, respectively $(\mathrm{p}=0.6424)$. This subanalysis of week 14 infliximab levels in patients with sustained response to infliximab $5 \mathrm{mg} / \mathrm{kg}$ and with or without immunomodulator use may not have had the statistical power to reveal all possible differences. Arias et $a l^{11}$ reported that median early postinduction serum infliximab trough levels were higher in patients with ulcerative colitis receiving combined infliximab and immunomodulator treatment than in patients treated with infliximab monotherapy $(10.5 \mu \mathrm{g} / \mathrm{mL}$ vs $7.9 \mu \mathrm{g} / \mathrm{mL}$, respectively; $\mathrm{p}=0.02$ ), while concomitant immunomodulator use did not affect loss of response and discontinuation rates. These findings may have established that combining infliximab with an immunomodulator, as seen in SONIC, ${ }^{12}$ may be efficacious owing to increased trough levels rather than any synergistic mechanisms. If confirmed, then prospectively using infliximab trough level to guide dosing may be a means of maintaining higher trough levels with infliximab without immunomodulator use. 
Only 25\% (37/147) and 33\% (47/144) of patients receiving scheduled maintenance infliximab 5 or $10 \mathrm{mg} / \mathrm{kg}$, respectively, sustained week 14 response through week 54 in the ACCENT I study. As ACCENT I criteria for sustained response were stricter than the endpoints of most clinical trials, the number of patients with sustained response reported here was smaller than the number of patients in remission (39\% and 45\%) reported in the scheduled maintenance infliximab 5 and $10 \mathrm{mg} / \mathrm{kg}$ groups, respectively, at week 30 in ACCENT I. ${ }^{1}$ Despite the $58 \%$ response rate to a single infliximab $5 \mathrm{mg} / \mathrm{kg}$ dose in ACCENT I, the data suggest that for the CD inflammatory burden, dose escalation may be required to sustain trough levels and response as early as week 14 in some patients. This was supported by the observation that no difference in week 14 serum infliximab trough levels was found between patients treated with scheduled maintenance infliximab $10 \mathrm{mg} / \mathrm{kg}$ with or without baseline immunomodulator use.

This ACCENT I post hoc analysis has some limitations. First, although all data and samples were prospectively collected during ACCENT I, this analysis was not prespecified and, therefore, cannot be considered conclusive. Second, we used sustained response (as defined by the ACCENT I protocol) and not sustained remission as an outcome measure for this analysis. Although clinical response is a less stringent outcome measure than remission in $\mathrm{CD}$, we wanted to assess the effect of sustained benefit since this may reflect a more routine practice approach. We also did not assess corticosteroid-free remission as an outcome measure. This outcome measure was the primary endpoint in the more recent SONIC trial but has not yet been used in analyses of ACCENT I data. Third, our definition of the week 14 infliximab cut-off value and of CRP change is based on only $49 \%(71 / 144)$ of patients included in this analysis and on $37 \%(71 / 192)$ of patients in the overall $5 \mathrm{mg} / \mathrm{kg}$ arm in ACCENT I. In addition, interindividual variation of serum infliximab trough levels is large (as shown in figure $3 \mathrm{~A}, \mathrm{~B}$, the median (IQR) box-and-whisker plots), and although a low $(<3.5 \mu \mathrm{g} / \mathrm{mL})$ week 14 infliximab trough level may be found in most patients without sustained response with NPV of 0.83 in ACCENT I, the predictive value of a single (week 14) infliximab trough level in individual patients with CD will need additional research. The ACCENT I design did not include early dose optimisation during the induction phase until week 14 . We do not know whether early dose optimisation, targeting a $\geq 3.5 \mu \mathrm{g} / \mathrm{mL}$ serum infliximab level by week 14 , might improve long-term clinical outcome. We therefore cannot recommend early dose adjustment in patients with asymptomatic CD receiving infliximab treatment without a prospective trial.

Our data indicate that the long-term benefit of a $5 \mathrm{mg} / \mathrm{kg}$ infliximab dose in CD may depend on an early postinduction serum infliximab level $\geq 3.5 \mu \mathrm{g} / \mathrm{mL}$. We do not know whether this cut-off level of $\geq 3.5 \mu \mathrm{g} / \mathrm{mL}$ for week 14 serum infliximab trough levels can be applied to other assay formats; however, we conclude that a measurable postinduction serum infliximab trough level is predictive of long-term sustained response without the need for dose increase. Because of the high NPV of the $<3.5 \mu \mathrm{g} / \mathrm{mL}$ serum trough level at week 14 in patients with $\mathrm{CD}$, the risk of ATI development and the clinical benefit of preventing $C D$ symptom recurrence, we suggest that serum infliximab levels should be raised from the beginning and throughout the course of CD treatment.

Antibodies to infliximab develop in a significant number of patients treated episodically and soon after the initial infusion. ${ }^{4}$ Episodic treatment cannot maintain measurable serum infliximab levels and may thus induce ATI formation. Episodic treatment of patients with CD has been mostly abandoned because relapsing patients suffer from symptoms and complications. The association of early week 14 serum infliximab levels $\geq 3.5 \mu \mathrm{g} /$ $\mathrm{mL}$ with sustained response to maintenance infliximab $5 \mathrm{mg} / \mathrm{kg}$ given every 8 weeks seen in these results supports the proposed role that detectable infliximab trough levels may prevent ATI formation.

In summary, early serum infliximab trough levels in association with a decrease in CRP predict the long-term clinical outcome in patients with CD. Our data confirm that maintaining raised serum infliximab trough levels from the start of treatment results in a sustained benefit. We defined the $3.5 \mu \mathrm{g} / \mathrm{mL}$ trough level as a useful postinduction cut-off point for induction and maintenance infliximab $5 \mathrm{mg} / \mathrm{kg}$ treatment. Our post hoc analysis thus adds important clinical information for the understanding and practical use of serum infliximab trough levels.

Acknowledgements We thank Lyn Lai and Gianna Paone of Janssen Scientific Affairs, LLC, for editorial assistance, manuscript preparation and submission support.

Contributors FC conceived the study and drafted the manuscript. SBH, RHD, ZX, PR and SV conceived the study. JW and KLT analysed the data. All authors interpreted the data, critically reviewed the manuscript for important intellectual content and approved the manuscript to submit for publication.

Funding Janssen Services, LLC, supported this study.

Competing interests FC, RHD, JW, KLT and ZX are/or were employed by the Janssen Pharmaceutical Companies of Johnson \& Johnson at the time of the study. SBH has served as a consultant for Janssen Biotech, Inc. PR and SV have no competing interests to declare. SBH, PR and SV received research support for the original ACCENT I study.

Provenance and peer review Not commissioned; externally peer reviewed.

Open Access This is an Open Access article distributed in accordance with the Creative Commons Attribution Non Commercial (CC BY-NC 3.0) license, which permits others to distribute, remix, adapt, build upon this work non-commercially, and license their derivative works on different terms, provided the original work is properly cited and the use is non-commercial. See: http://creativecommons.org/ licenses/by-nc/3.0/

\section{REFERENCES}

1 Hanauer SB, Feagan BG, Lichtenstein GR, et al; and the ACCENT I Study Group. Maintenance infliximab for Crohn's disease: the ACCENT I randomised trial. Lancet 2002;359:1541-9.

2 Ben-Horin S, Chowers Y. Review article: loss of response to anti-TNF treatments in Crohn's disease. Aliment Pharmacol Ther 2011;33:987-95.

3 Maser EA, Villela R, Silverberg MS, et al. Association of trough serum infliximab to clinical outcome after scheduled maintenance treatment for Crohn's disease. Clin Gastroenterol Hepatol 2006;4:1248-54.

4 Baert $F$, Noman $M$, Vermeire $S$, et al. Influence of immunogenicity on the long-term efficacy of infliximab in Crohn's disease. N Engl J Med 2003;348:601-8.

5 Rutgeerts P, Feagan BG, Lichtenstein GR, et al. Comparison of scheduled and episodic treatment strategies of infliximab in Crohn's disease. Gastroenterology 2004;126:402-13.

6 Hanauer SB, Wagner CL, Bala M, et al. Incidence and importance of antibody responses to infliximab after maintenance or episodic treatment in Crohn's disease. Clin Gastroenterol Hepatol 2004;2:542-53.

7 Reinisch W, Wang Y, Oddens BJ, et al. C-reactive protein, an indicator for maintained response or remission to infliximab in patients with Crohn's disease: a post-hoc analysis from ACCENT I. Aliment Pharmacol Ther 2012;35:568-76.

8 Jürgens M, Mahachie John JM, Cleynen I, et al. Levels of C-reactive protein are associated with response to infliximab therapy in patients with Crohn's disease. Clin Gastroenterol Hepatol 2011;9:421-7 e1.

9 Cornillie F, Hanauer SB, Diamond RH, et al. Can clinical, biological or pharmacological markers predict sustained response to infliximab? A retrospective analysis of ACCENT I [abstract]. Gut 2011;60(Suppl 3):A296. United European Gastroenterology Week. Stockholm, Sweden 2011

10 Schnitzler F, Fidder $H$, Ferrante $M$, et al. Mucosal healing predicts long-term outcome of maintenance therapy with infliximab in Crohn's disease. Inflamm Bowel Dis 2009;15:1295-301.

11 Arias MT, Vande Casteele N, Drobne D, et al. Importance of trough levels and antibodies on the long-term efficacy of infliximab therapy in ulcerative colitis [abstract]. J Crohns Colitis 2012;6(Suppl 1):S5.

12 Colombel JF, Sandborn WJ, Reinisch W, et al; for the SONIC Study Group. Infliximab, azathioprine, or combination therapy for Crohn's disease. N Engl J Med 2010;362:1383-95. 